\title{
Implications of breed, sexual dimorphism and age on aspartate aminotransferase (AST) levels in the blood serum of sheep managed under traditional extensive system
}

\begin{abstract}
Serum biochemical traits constitute important panels in the clinical diagnosis, prognosis and treatment of livestock diseases via the investigations of myriads of parameters influencing these biochemical references. Sixty clinically healthy animals of three extant breeds of Nigerian native sheep (20 Balami: 20 Yankassa and 20 Uda) were sampled to examine the roles of breed, age and sexual dimorphism on aspartate aminotransferase levels in the blood stream of tropically managed sheep. We present from our study that breed difference exerted no significance effect on serum aspartate aminotransferase levels of sheep considered but a numerically high levels were obtained in Yankassa $(179.35 \pm 10.17 \mathrm{UI} / \mathrm{dl})$ relative to the least serum AST levels obtained in Uda $(157.68 \pm 7.16 \mathrm{IU} / \mathrm{dl})$. Our findings revealed that sexual dimorphism had no marked influence on the serum AST levels examined but it was found that the AST levels in rams $(176.09 \pm 8.52 \mathrm{IU} / \mathrm{dl})$ were higher relative to the ewes $(169.47 \pm 7.32 \mathrm{IU} / \mathrm{dl})$. In the same trend, age had no evident influence on serum AST levels examined. Therefore, this study affirms that breed, age and sexual dimorphism do not provoke abnormally high levels of serum enzyme (AST) in the blood serum of sheep managed under tropical condition.
\end{abstract}

Keywords: serum enzyme, aspartate aminotransferase (AST), sexual dimorphism, breeds
Volume 5 Issue 5 - 2017

\author{
Gbolabo Olaitan Onasanya,' Amusan Samuel \\ Ayotunde, ${ }^{2}$ Muyideen Timothy Sanni, ${ }^{2}$ \\ Mathew Wheto, ${ }^{2}$ Christian Obiora Ndubuisi \\ Ikeobi, ${ }^{2}$ John S Decampos, ${ }^{2}$ Abiodun Oni ${ }^{2}$ \\ 'Department of Animal Science, Federal University, Nigeria \\ ${ }^{2}$ Department of Animal Breeding and Genetics, Federal \\ University of Agriculture, Nigeria
}

\begin{abstract}
Correspondence: Gbolabo Olaitan Onasanya, Department of Animal Science, Federal University, Dutse, Nigeria,Tel +2347 069209 207, Email onasanya.gbolabo@gmail.com, gbolaboonasanyainfud@gmail.com
\end{abstract}

Received: April 04, 2017 | Published: July 10, 2017

\section{Introduction}

Serum biochemical references constitute important panels in the clinical diagnosis, prognosis and treatment of livestock diseases via the investigations of myriads of parameters influencing these biochemical traits. ${ }^{1}$ Serum biochemical values are excellent health indicators and can reliably assess the health status of animals as changes in these serum biochemical references are critical indicators of pathophysiological responses under disease assaults such as trypanosomosis that can elicit abnormal increase in aspartate aminotransferase enzyme or Aspartate transaminase (AST) levels in the blood stream. ${ }^{2-4}$ Both blood urea nitrogen and alkaline phosphatase enzyme were higher in T. Vivax-infected sheep where it was reported that insect infestation such as $T_{s e}$-Tse fly can cause unexpected increase in serum enzymes levels in sheep. ${ }^{3}$ Similarly, Taiwo et al. ${ }^{5}$ reported increased alkaline phosphatase enzyme (ALP) and alanine transaminase enzyme (ALT)/ alanine aminotransferase (AST) levels in blood stream of T. Vivaxinfected animals due to breakdown and inflammation of liver, heart, muscle and kidney by Tse-Tse fly infestation. Thus, unexpected increase in AST and ALT levels in blood stream of Tse-Tse fly infested animal is an indication of damaged and malfunctioning liver and kidney inability to clear the blood of excess serum enzymes ${ }^{5-8}$ as this can be clinically employed in tracking many diseases. The presence of elevated AST (serum glutamic oxaloacetic transaminase-SGOT), ALT (serum glutamic pyruvic transaminase-SPGT) levels in blood stream are critical indicator of liver and cardiac damage and malfunctioning as they equally play a catalytic roles in synthesis of amino acid by reversible exchange of amine group $\left(\mathrm{NH}_{2}\right)$ and keto group $(=\mathrm{O}){ }^{9-11}$ Therefore, this study intends to examine the roles of breed, age and sex in the activities of serum AST enzyme in blood stream of sheep managed under tropical condition.

\section{Materials and methods}

Sixty clinically healthy sheep were sampled from South-west area of Nigeria. Three extant breeds of Nigerian native sheep (Balami: 20; Yankassa: 20 and Uda: 20) of different age group (1-2, 2-3 and 3-4years) were sampled and 5, 25 and 30 animals were sampled per age group respectively. The ages of the animals were estimated by dentition (presence of 2-8 permanent incisors). The animals, originated from different herds, were reared under the traditional extensive system where they grazed during the day on natural pasture containing forages such as stylo (Stylosanthes gracilis), leucaena (Leucaena leucocephala) and guinea grass (Panicum maximum), crop residues and scavenged on kitchen remnant whenever available. The animals were individually bled via the jugular vein and blood samples were collected from individual animals into heparinized tubes to coagulate and immediately transferred to laboratory for serum biochemical analyses of aspartate amino transferase enzyme. ${ }^{12}$

\section{Statistical analyses}

All data collected were estimated using PROC GLM of SAS version 9.1 .

The linear model employed was: 
$Y_{i j}=\mu+A_{i}+B_{j}+C_{k}+D_{i j}+E_{i k}+F_{j k}+\mathrm{e}_{i j k}$

$Y_{i j}:$ Trait of interest

$\mu$ : Population mean

$A_{i}:$ Effect of $i^{\text {th }}$ breed (Balami, Yankassa and Uda)

$B_{j}$ : Effect of $j^{\text {th }} \operatorname{sex}(1-2)$

$C_{k}$ : Effect of $k^{\text {th }}$ age (1-4)

$D_{i j}$ : Effect of $i^{\text {th }}$ breed and $j^{\text {th }}$ sex interaction

$E_{i k}$ : Effect of $i^{\text {th }}$ breed and $k^{\text {th }}$ age interaction

$F_{j k}$ : Effect of $j^{\text {th }}$ sex and $k^{\text {th }}$ age interaction

$\mathrm{e}_{i j k}$ : Random error associated with each record (assumed to be normally, independently and identically distributed with zero mean and constant variance). The means were separated using Duncan multiple range test.

\section{Results}

We present from our study that sexual dimorphism influence exerted no evident $(\mathrm{p}>0.05)$ effect on the serum AST levels of sheep considered but ram had a numerically higher serum AST levels $(176.09 \pm 8.52 \mathrm{IU} / \mathrm{dl})$ relative to its ewe $(169.47 \pm 7.32 \mathrm{IU} / \mathrm{dl})$ counterparts (Table 1). Age of the sheep had no marked $(\mathrm{p}=0.05)$ implication on the serum AST levels (Table 2). Table 3 showed that breed of the sheep had no evident implication $(\mathrm{p}=0.05)$ on serum AST levels considered but it was found that Yankassa had higher serum AST levels $(179.35 \pm 10.17 \mathrm{IU} / \mathrm{dl})$ relative to least serum AST levels $(157.68 \pm 7.16 \mathrm{IU} / \mathrm{dl})$ recorded in Uda. The findings of this study showed that age and sex interaction had no evident influence $(\mathrm{p}=0.05)$ on the serum AST levels of sheep examined but a higher serum AST levels $(188.20 \pm 11.57 \mathrm{IU} / \mathrm{dl})$ were found in ram between the ages of 1-2years relative to least serum AST levels (159.0 $\pm 9.65 \mathrm{IU} /$ dl) recorded in ram under one year (Table 4).

Though, breed and sex interaction had no significant $(\mathrm{p}=0.05)$ effect on the serum AST levels of sheep examined but it was found that rams had higher serum AST levels relative to the ewes, where higher serum AST level (186.54 $\pm 9.30 \mathrm{IU} / \mathrm{dl})$ was recorded in Yankassa ram relative to the least value recorded in Uda ram and ewe $(159.20 \pm 9.45 \mathrm{IU} / \mathrm{dl})$ as shown in Table 5. Breed and age interaction exerted no marked implication $(\mathrm{p}=0.05)$ on AST levels of sheep considered but a higher numerical levels $(193.72 \pm 11.6 \mathrm{IU} / \mathrm{dl})$ were obtained in Yankassa lamb between the ages of 1-2years relative to the least serum AST levels $(137.95 \pm 5.6 \mathrm{IU} / \mathrm{dl})$ recorded in Uda sheep between the ages of 3-4years (Table 6).

Table I Means of main effect of sex on AST levels in blood serum of sheep

\begin{tabular}{cc} 
Sex & AST (IU/dl) \\
\hline Ram & $176.09 \pm 8.52^{\mathrm{a}}$ \\
Ewe & $169.47 \pm 7.32^{\mathrm{a}}$
\end{tabular}

Means with the same superscripts within the same column are not significantly different $(p=0.05)$
Table 2 Means of main effect of age on AST levels in blood serum of sheep

\begin{tabular}{ll}
\hline Age (Year) & AST (IU/dI) \\
\hline$<I$ & $1.24 \pm 0.58^{\mathrm{a}}$ \\
2-Jan & $1.77 \pm 0.48^{\mathrm{a}}$ \\
3-Feb & $1.65 \pm 0.56^{\mathrm{a}}$ \\
$4-\mathrm{Mar}$ & $1.66 \pm 0.55^{\mathrm{a}}$ \\
\hline
\end{tabular}

Means with the same superscripts within the same column are not significantly different $(p=0.05)$

Table 3 Means of main effect of breed on AST levels in blood serum of sheep

\begin{tabular}{ll}
\hline Breed & AST $($ IU/dI) \\
\hline Yankassa & $179.35 \pm 10.17^{a}$ \\
Balami & $169.44 \pm 9.14^{a}$ \\
Uda & $157.68 \pm 7.16^{a}$
\end{tabular}

Means with the same superscripts within the same column are not significantly different $(p=0.05)$

Table 4 Means of interaction effect of age and sex on AST levels in blood serum of sheep

\begin{tabular}{lll}
\hline Age(Year) X & Sex & AST (IU/dI) \\
\hline$<1$ & Ram & $159.00 \pm 9.65^{\mathrm{a}}$ \\
& Ewe & $178.23 \pm 11.97^{\mathrm{a}}$ \\
2-Jan & Ram & $188.20 \pm 11.57^{\mathrm{a}}$ \\
& Ewe & $166.43 \pm 8.96^{\mathrm{a}}$ \\
3-Feb & Ram & $166.14 \pm 10.55^{\mathrm{a}}$ \\
& Ewe & $165.79 \pm 10.45^{\mathrm{a}}$ \\
& Ram & $171.62 \pm 11.43^{\mathrm{a}}$ \\
& Ewe & $164.24 \pm 10.57^{\mathrm{a}}$
\end{tabular}

Means with the same superscripts within the same column are not significantly different $(p=0.05)$

Table 5 Means of interaction effect of breed and sex on AST levels in blood serum of sheep

\begin{tabular}{lll}
\hline Breed X & Sex & AST (IU/dI) \\
Yankassa & Ram & $186.54 \pm 9.30^{\mathrm{a}}$ \\
& Ewe & $175.43 \pm 9.38^{\mathrm{a}}$ \\
Balami & Ram & $177.50 \pm 9.80^{\mathrm{a}}$ \\
& Ewe & $162.54 \pm 9.77^{\mathrm{a}}$ \\
Uda & Ram & $159.20 \pm 9.45^{\mathrm{a}}$ \\
& Ewe & $159.20 \pm 9.45^{\mathrm{a}}$
\end{tabular}

Means with the same superscripts within the same column are not significantly different $(p=0.05)$ 
Table 6 Means of interaction effect of breed and age on AST levels in blood serum of sheep

\begin{tabular}{lll}
\hline Breed X & Age (Year) & AST (IU/dI) \\
\hline \multirow{3}{*}{ Yankassa } & 2-Jan & $185.20 \pm 10.75^{\mathrm{a}}$ \\
& 3-Feb & $193.72 \pm 11.65^{\mathrm{a}}$ \\
& $4-\mathrm{Mar}$ & $181.60 \pm 9.75^{\mathrm{a}}$ \\
& $<1$ & $189.68 \pm 12.77^{\mathrm{a}}$ \\
Balami & 2-Jan & $147.90 \pm 7.66^{\mathrm{a}}$ \\
& 3-Feb & $212.25 \pm 11.56^{\mathrm{a}}$ \\
& $4-\mathrm{Mar}$ & $166.40 \pm 13.58^{\mathrm{a}}$ \\
& $<1$ & $159.85 \pm 12.59^{\mathrm{a}}$ \\
& 2-Jan & $145.92 \pm 10.60^{\mathrm{a}}$ \\
& 3-Feb & $140.02 \pm 1.75^{\mathrm{a}}$ \\
& $4-M a r$ & $137.95 \pm 9.56^{\mathrm{a}}$
\end{tabular}

Means with the same superscripts within the same column are not significantly different $(p=0.05)$

\section{Discussion}

An activity of serum AST enzymes was not affected by increase in age as this corroborates earlier findings of Dubreuil et al. ${ }^{13}$ who reported that increase in age does not evidently influence activities of serum AST and other related enzymes. Though effect of sexual dimorphism was not significant on the activities of AST enzyme in this study, the ram seems to have higher serum AST levels relative to ewe. This disagrees with earlier reports that sex of animals had significantly evident influence on serum AST enzyme with higher AST values documented for female relative to male animal. A possible explanation for sex difference is related to the adrenal cortex, since there is a sex difference in adrenal function which is dependent on ovarian activity ${ }^{14}$ and physiology of the ewe. Breed of sheep did not influence serum AST levels. However, unexpected increase in AST levels in blood stream of animal is an indication of damaged and mal-functioning liver and kidney inability to clear the blood of excess serum enzymes. ${ }^{5-8}$ Similarly, the presence of elevated AST (serum glutamic oxaloacetic transaminase-SGOT), ALT (serum glutamic pyruvic transaminase-SPGT) levels in blood stream are critical indicator of liver and cardiac damage and malfunctioning. ${ }^{5-11}$

\section{Conclusion}

This study affirms that breed, age and sexual dimorphism do not influence the activities of AST enzyme in the blood serum of sheep managed under tropical condition. Other factors such as disease, insect infestation, nutrition/diet, etc. could further be examined as culprits that may provoke unexpected increase in levels of AST enzymes in blood serum of tropically-managed sheep as this constitute an excellent health indicator in the diagnosis and prognosis of the clinical health conditions of animals reared under hash condition of the tropics.

\section{Acknowledgements}

None.

\section{Conflict of interest}

Author declares that there is no conflict of interest.

\section{References}

1. Onasanya GO, Oke FO, Sanni TM, et al. Parameters Influencing Haematological, Serum and Bio-Chemical References in Livestock Animals under Different Management Systems. Open Journal of Veterinary Medicine. 2015;5(8):181-189.

2. Neils JS, Sackey AK, Abdullahi US, et al. Trace minerals in serum of sheep infected with Trypanosoma congolense. Pak J Biol Sci. 2007;10(2):310-313.

3. Anene BM, Ifebigh A, Igwilo IA, et al. Prevalence and haemato-biochemical parameters of trypanosomes infected pigs at Nsukka, Nigeria. Comp Clin Pathol. 2011;20(1):15-18.

4. Omeje JN, Anene BM. Comparative serum biochemical changes induced by experimental infection of T. brucei and T. congolense in pigs. Vet Parasitol. 2012;190(3-4):368-374.

5. Taiwo VO, Looney MO, Ogunsanmi AO. Comparative plasma biochemical changes and susceptibility of erythrocytes to in vitro peroxidation during 318 experimental Trypanosoma Congolese and T. brucei infections in sheep. Israel Journal of Veterinary Medicine. 2003;58:4.

6. Obaleye JA, Akinremi CA, Balogun EA, et al. Toxicological studies and antimicrobial properties of some Iron (III) complexes of ciprofloxacin. Afri J Biotechnol. 2007;6(24):2826-2832.

7. Wurochekke AU, Anthony AE, Obidah W. Biochemical effects on the liver and kidney of rats administered aqueous stem bark extract of $\mathrm{Xe}$ menia Americana. Afri J Biotechnol. 2008;7(16):2777-2780.

8. Oyewole OI, Malomo SO. Toxicological assessment of oral administration of some anti-sickling agents in rats. Afri $J$ Biochem Res. 2009;3(2):024-028.

9. Karmen A. A note on the spectrometric assay of glutamic-oxalacetic transaminase in human blood serum. The Journal of clinical investigation. 1955;34(1):131-133.

10. Karmen A, Wroblewski F, Ladue JS. Transaminase activity in human blood. J Clin Invest. 1955;34(1):126-131.

11. Ladue JS, Wroblewski F, Karmen A. Serum glutamic oxaloacetic transaminase activity in human acute transmural myocardial infarction. Science. 1954;120(3117):497-499.

12. Jain NC. Schalman's Veterinary haematology. 4th ed. Philadelphia: Lea and Babings; 1986. p. 208-224.

13. Dubreuil P, Arsenault J, Bélanger D. Biochemical reference ranges for groups of Ewes of different. Vet Rec. 2005;156(20):636-638.

14. Critchlow V, Liebelt RA, Bar-Sela M, et al. Sex difference in resting pituitary adrenal function in the Rat. Am J Physiol. 1963;205(1):807-815. 